Information for citation:

Chesalina, O. V. (2021) The Scope of Labour Law in the Platform Economy. European and Asian Law Review. 4 (1), 28-35. DOI: 10.34076/27821668_2021_4_1_28.

UDC 349.2

BISAC LAW054000

DOI: $10.34076 / 27821668 \_2021 \_4 \_1 \_28$

Research article

\title{
THE SCOPE OF LABOUR LAW IN THE PLATFORM ECONOMY
}

\author{
OLGA V. CHESALINA \\ Max-Planck-Institute for Social Law and Social Policy \\ ORCID ID: 0000-0002-1092-7286
}

The development of the digital economy, accompanied by new forms of employment, has an impact on the scope of labour law. Using systemic, formal legal and comparative legal methods, the article explores strategies directed on expanding the scope of labour law at national, European and international levels. The article reflects the actual narrowing of the scope of labour law; it considers case law on the legal status of platform workers and analyses the policies of the International Labour Organisation, the European Union and several Member States of EU aimed at expanding the scope of labour law guarantees. In the author's opinion, when courts classify legal relations with platform workers as labour relations, it is correct to speak about preventing an unreasonable narrowing of the scope of labour law rather than about an extension of the scope of labour law. A new interpretation by courts of already existing characteristics of an employment relationship will prevent the circumvention of labour law regulations by platform providers and their partners.

Keywords: labour law; employment relationship; intermediate employment category; platform workers; employee; self-employed; algorithmic control

\section{Introduction}

The scope of labor law is determined on the basis of a binary model (employee and employer) in many countries. Considering European countries, it should be noted that the binary model is typical for almost all Eastern European countries, while in a number of Western European countries (for example, Austria, Germany, Italy, Spain, Great Britain) intermediate employment categories are provided. It is important to note that working people falling into the intermediate category in these countries, despite the fact that they are endowed with some labor rights, are considered to be self-employed. Although in some countries of Eastern Europe there have been proposals in favor of an intermediate category (for example, in Hungary), the legislatively intermediate category 'economically dependent persons' has been provided only in Slovenia since 2013 (Gyulavári, 2020: 550; Gyulavári, 2014).

The binary model arose at a time when the worker and the self-employed person (entrepreneur) represented two diametrically opposed categories. The employee was a 'weak' party, deprived of the means of production and in need of social protection, and the entrepreneur could independently determine the conditions of his work and the prices for the work he performed and the services provided. Currently, the structure of self-employment has changed: the number of self-employed (entrepreneurs) without hired workers is growing (Joyce \& Stuart 2019: 18); for every fifth self-employed person, this form of employment is compulsory due to the lack of alternatives in the labor market (Joyce \& Stuart 2019: 18); there are more and more self-employed people who work part-time, although initially this was not at all typical for independent work (Choonara, 2019: 113). 
It is common for employers to look for ways to optimize labor costs and develop business models for this purpose aimed at avoiding the application of labor law and legal guarantees. An example is personnel outsourcing, personnel leasing and the conclusion of civil law contracts instead of employment contracts. In this regard, the number of bogus self-employed persons is growing. In the last six years, one of the most talked about issues in labor law has become the business model of work through platforms and platform employment. Especially in the early years after the appearance of this approach, the phrase of the CEO of the Crowdflower platform was widely quoted: 'Until the Internet was invented, it would be very difficult to find someone who ... would work for you for ten minutes and who then, after 10 minutes, could be fired. But having the technology, you can find people like that, pay them some money and get rid of them when you no longer need them'1. Despite the fact that the work of persons who provide services 'offline' through platforms and mobile applications (for example, transport services, cleaning services or food delivery) contains features of an employment relationship (depending on the type of platform and the type of service provided, the number of features of an employment relationship may vary), in practice such activities are still often viewed as independent work. Platform providers unilaterally determine the procedure for the provision of platform employed services to customers (clients) and treat them as self-employed persons (De Stefano \& Durri 2021: 12-17). As platform operators seek to avoid the application of labor law, there is a de facto narrowing of the circle of persons to whom labor law applies.

\section{Materials and methods}

This article focuses on changes in the scope of labor law in the platform economy. Using systemic, formal legal and comparative legal methods, strategies are being studied aimed at expanding the scope of labor law at the national, European and international levels. Both Russian and foreign judicial practice regarding the presence of features of an employment relationship in new forms of employment is analyzed.

\section{Results}

The research results are formulated in the conclusions.

\section{Discussion}

\section{Trends in the scope of labor law}

Currently, two interrelated trends are clearly noted. Firstly, it is an obstruction (by the courts and the legislator) of circumvention of labor legislation by platform providers and their partners, primarily in cases of provision of transport, courier and some other services by platform employees, i.e. preventing the actual narrowing of the scope of labor law. Secondly, a policy is being pursued aimed at expanding the scope of labor and legal guarantees and ensuring equal access to social protection regardless of the form of employment at the international, European and national level. Let's consider these trends in sequence.

The first trend is disclosure of the essence of platform employment in the judicial practice of foreign countries

In recent years, many decisions have been made in different countries about the legal status of couriers and drivers who work through platforms. Although the jurisprudence is not uniform, there has been a certain tendency to recognize platform workers as workers or persons in the intermediate category (for example, a worker in the UK). Despite the fact that platform providers position themselves as intermediaries that provide only information services, courts in many countries (for example, France, Italy, Spain, Germany, Great Britain, etc.) were able to correctly determine the essence of the platform employment structure and evaluate the algorithmic control (Engler, 2019; Gruber-Risak, 2021). In this case, the courts proceeded from the priority of facts when considering disputes; resolved disputes by re-interpreting existing criteria for an employment relationship, and in some cases, developed new criteria for an employment relationship. In particular, courts in many countries have concluded that subordination and personal dependence of the platform employee on the platform operator arise on the basis of algorithmic control. Thus, the judicial

\footnotetext{
${ }^{1}$ Marvit, M. Z. (05 February 2014) How Crowdworkers Became the Ghosts in the Digital Machine. The Nation. Available from: http://www.thenation.com/article/how-crowdworkers-became-ghosts-digital-machine/ [Accessed: 15 April 2021 ].
} 
practice in a number of cases proceeds from the fact that algorithmic dependence is not a new type of dependence, but it is a modified feature of the personal dependence of the platform employee on the platform provider. For example, the Ontario Labor Relations Board found the mobile app to be far more important than the bicycle in the case of courier activities for the Foodora platform; the mobile application plays the most important part in the food delivery process, it is owned and controlled by Foodora (ILAW, 2021). The German Federal Labor Court in its decision of December 1, 2020 (AZR 102/20) in the first dispute on platform employment notes that in order to recognize the occurrence of an employment relationship, the customer must take organizational measures by which the employed person, even not directly prescribed, but this person indirectly inclines to consistently accepting orders and fulfilling them at certain intervals according to clearly defined parameters. In this case, personal addiction can arise through the incentive system implemented by the platform and the provided mobile application. The platform deliberately splits one large task into a large number of micro-tasks, which separately have no economic value. The mobile application regulates the conditions for the execution of orders in such a way that such activity from an economic point of view makes sense only if orders are accepted regularly and for a long time and are carried out according to the instructions set in the application in advance.

The second trend is expansion of the scope of application of labor law in ILO and EU instruments

Both the International Labor Organization and the European Union are pursuing policies aimed at expanding the scope of labor and legal guarantees and social security in response to the changing structure of the self-employed and the proliferation of economically dependent self-employed. It should be noted that some ILO Conventions and Recommendations apply not only to workers with whom an employment contract is concluded, but also to self-employed and to those employed in the informal sector of the economy. Examples are ILO Convention No. 182 on the Elimination of the Worst Forms of Child Labor; ILO Convention No. 29 on the Prohibition of Forced Labor, as well as a number of ILO Conventions on the Prohibition of Discrimination (ILO Convention No. 100 on Equal Remuneration for Men and Women for Work of Equal Value, ILO Convention No. 111 on Discrimination in Employment and Occupation) (De Stefano, 2021). At the same time, it is important to emphasize that those ILO standards that apply to the self-employed and those employed in the informal sector of the economy are most often formulated as prohibitions (of discrimination, forced labor), and not as clear positive norms defining the scope of a particular Convention or Recommendation. The ILO Global Commission on the Issues of Future of Work has proposed the development of a universal labor guarantee, which should include fundamental principles and rights at work and apply to all workers, regardless of the type of contract concluded with them and their employment status (De Stefano, 2021). The final text of the 2019 ILO Centenary Declaration on the Future of Work did not include such broad wording. The Declaration states that all workers (and not all employees, regardless of the form of employment) must be provided with adequate protection (letter B). In recent years, the European Union has demonstrated an even broader approach than the ILO regarding the expansion of the scope of social and legal and labor legal guarantees. The European Commission's work program for 2021 announced an initiative to improve the working conditions of service providers through platforms ${ }^{2}$, many of whom are still self-employed. Another initiative of the European Commission concerns the conclusion of collective agreements for self-employed persons, emphasizing that 'persons providing services through platforms, as well as persons working on the basis of civil law contracts, often do not participate in determining the price of their services and may not be able to conduct negotiations on the terms on which they will provide services's. To date, it is not yet clear as to which groups of the selfemployed will be covered by this initiative.

Intermediate category as a way to expand the scope of labor law

Different countries are discussing and applying different strategies to expand the scope of employment law. One of these strategies is the introduction of intermediate categories of the employed population.

\footnotetext{
${ }^{2}$ European Commission (24 February 2021) First Phase Consultation of Social Partners under Article 154 TFEU on Possible Action Addressing the Challenges Related to Working Conditions in Platform Work. Brussels. C(2021) 1127 final. Available from: https://ec.europa.eu/commission/presscorner/detail/en/qanda_21_656 [Accessed 15 April 2021].

3 European Commission (2021) Collective Bargaining Agreements for Self-employed - Scope of Application of EU Competition Rules. Inception Impact Assessment No. 102652. Available from: https://ec.europa.eu/info/law/betterregulation/have-your-say/initiatives/12483-Collective-bargaining-agreements-for-self-employed-scope-of-application-EUcompetition-rules [Accessed 15 April 2021].
} 


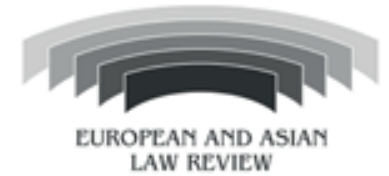

Vol 4. Is. 1

Since platform employment often contains features of both independent and dependent work (Zaitseva \& Mitryasova, 2018: 241; Diveeva \& Grebenshikov, 2020), scientists are actively discussing the need to introduce new intermediate categories in order to reflect the specifics of this new form of employment (Zaitseva \& Mitryasova, 2018: 243; Korshunova, 2020; Shuraleva, 2019; Harris \& Kruger, 2015; Ljutov \& Voitkovska, 2021). The introduction of an intermediate category of employment can lead, on the one hand, to the expansion of the scope of labor legislation by covering persons to whom these norms were not previously applied, and the extension of certain labor-legal guarantees to such persons. But, on the other hand, there may be a narrowing of the scope of labor legislation, since many employers may try to retrain workers in the intermediate category in order to optimize costs. Thus, the introduction of such a new category will lead to a decrease in the level of protection (labor and social) for both workers and persons falling under the new category (Prassl \& Gruber-Risak, 2017). In practice, the situation has already developed in this way, for example in Italy after the introduction of the category 'quasi-subordinate' (Cherry \& Aloisi, 2017). Also in California, platform companies invested \$ 200 million in 2020 to campaign against AB5, which set new criteria for qualifying platform workers as workers, and initiated legislative initiative Proposition 22. Proposition 22, passed on November 3, 2020 in California, effectively creates an intermediate category between the employee and the independent contractor, to whom some social protection is provided (guarantee of a minimum remuneration during the provision of a service, protection against accidents, compensation for certain costs associated with vehicle maintenance), but the level of this protection is much lower than the level of protection guaranteed to workers (Cherry, 2021). In order to prevent a narrowing of the scope of application of labor law when introducing intermediate categories, it is advisable to extend to such persons the legal regulations of workers (that is, to endow them with labor rights and guarantees that employees have). It is precisely this regulation that has been provided for many decades in Canada (Cherry \& Aloisi, 2017: 651-656), and since 2019 similar regulation has also been in effect in Italy for platform workers (De Stefano \& Durri, 2021: 21). In addition, conditions should be excluded that would allow potential employers (customers) to abuse the use of labor of persons who are in the intermediate category or are bogus self-employed, in particular, expand the scope of legislation on social security; harmonize the conditions under which social security is provided to all workers, regardless of the form of employment; assign the responsibility of paying insurance premiums and social security to customers, platform operators, etc.

Expansion of the scope of application of labor law in the legislation of individual EU member states

The expansion of the scope of application of labor law also occurs through the provision of labor rights to self-employed persons. For example, in Italy, by Law No. 81 of May 22, 2017, for the first time, all self-employed persons were granted rights in labor legislation, some of which are the preservation of remuneration during illness, pregnancy or an accident (such guarantees are provided by the state, and not by the customer) - similar to labor rights of workers (Gramano \& Stolzenberg, 2018: 200).

In France, a law (Loi d'Orientation des Mobilités) was passed in 2019 to ensure that platform providers voluntarily provide some social guarantees to drivers and couriers. Such guarantees were to be established in charters adopted by the platform operators; at the same time, the provision of such social guarantees and rights should not have been considered as a sign of legal subordination between the platform and the person working through the platform, that is, as a sign of an employment relationship (Kessler, 2021: 271). On December 20, 2019, the Constitutional Council declared unconstitutional a mechanism that allows platform operators to unilaterally determine the features and type of legal relationship with platform employees (Kessler, 2021: 273). According to article 34 of the French Constitution, the law establishes the basic principles of labor law, trade union law and social security. One of the basic principles of labor law is the definition of the scope of labor law. Therefore, private actors cannot determine what factors labor courts should consider as features of employment relationships (De Stefano \& Durri, 2021: 20).

Some countries (for example, Spain, Portugal) have passed laws regulating the provision of transport and delivery services through platforms in the past few years. For example, in Spain, such a law provides for a special (concerning only these groups of employed persons) presumption of labor legal relations with drivers, couriers (De Stefano \& Durri, 2021: 22).

Russian jurisprudence on the legal status of platform employees

Comparing the Russian judicial practice with foreign judicial practice on the recognition of relations with platform employed labor; the following conclusions can be drawn. To date, Russian courts deny drivers 
and couriers working through platforms to recognize the relationship as labor. Such decisions are justified by the following factors: no personnel decisions were made in relation to the platform employed by the service partner; a civil law contract was concluded with a platform employee, not an employment contract; no job order was issued; information about the work was not entered in the work book; the platform employee was not entrusted with the performance of the labor function (Chesalina, 2020b: 110; Ljutov \& Voitkovska, 2020: 155). Following this logic, any employer wishing to bypass labor legislation needs only to fail to fulfill the duties imposed on him by the Labor Code of the Russian Federation: not to issue an order for employment; not recognize the employee's right to weekends and annual leave; not pay for travel expenses, etc. In other words, this approach cannot protect an employee from an unscrupulous employer. The decisions made are based not on actual circumstances, but on how the relationship between the parties was formalized. This approach contradicts the position of the Supreme Court of the Russian Federation, set out in the Resolution of the Plenum of May 29, 2018 No. $15^{4}$ according to which the courts should not only proceed from the presence (or absence) of certain formalized documents, but also establish whether there were actually features of labor relations, i.e., proceed from the principle of the priority of facts. I will add that in this case it is important not only to proceed from the principle of the priority of facts, but also to correctly assess the factual circumstances of the case.

Platform employees in Russia, as well as in other countries, cannot have any influence either on the conditions for the provision of services by them to customers (clients), or on their legal status. Access to the service is provided only by accepting the terms of the offer and confirming the application of the

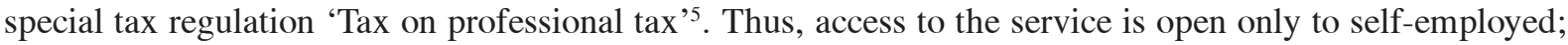
platform operators determine in advance the type of legal relationship with platform employees. But the courts proceed from the fact that the platform employed voluntarily chose this form of employment.

The courts do not properly assess the mobile application and algorithmic control (Ivanova \& Bronowicka, 2018; Prass1, 2018; Chesalina, 2020a), which is used by platform providers. The court decisions only state, for example, that 'the parties, when fulfilling their obligations under this agreement, use the application: a complex software and hardware solution for computers and mobile devices, through which the customer places orders, and the executor accepts them for execution and reports on execution' 6 ; "the interaction of couriers and the defendant's employees is solely due to the specifics of the Delivery Club service and the DC Ridder App'7. The courts do not analyze the fact that the management of the work process and the control of platform employees is carried out using a mobile application developed on the basis of the notions of the platform provider. Instead of personal instructions from the employer, the mobile application prescribes the sequence of actions when performing work; allows you to distribute platform employees by shifts and customers. Aggregators themselves confirm the use of algorithmic control. Thus, Delivery Club admits that it is improving technologies for finding and distributing couriers for orders, for which it hired about 150 developers in 2020. In particular, the company has optimized the auto-assignment algorithm responsible for distributing couriers to orders ${ }^{8}$. Thus, the courts do not take into account the new way of management and control of the labor process and the fact that the mobile application, algorithmic control replace managerial management on the part of the employer's representatives.

Often, to circumvent the emergence of an employment relationship, an additional (intermediate) participant is included in the platform employment model as a partner of the service (platform, aggregator), and in this case, a civil contract is concluded between the partner and the platform employee (for example, a lease or sublease of a vehicle, a work contract), agency agreement, contract for the provision of transport or courier services). Therefore, in Russia, claims to establish the fact of labor legal relations are brought by drivers and couriers not to the aggregator (platform), but to the service partner. The courts refuse to

\footnotetext{
${ }^{4}$ Resolution of the Plenum of the Supreme Court of the Russian Federation of May 29, 2018 No. 15 'On the Application by Courts of Legislation Regulating the Labor of Employees Working for Employers - Individuals and Employers - Small Businesses that are Classified as Microenterprises'. Consultant-Plus Database.

${ }^{5}$ Appeal Ruling of the Moscow City Court of November 22, 2019, case No. 33-53437/2019; Ruling of the Second General Jurisdiction Court of Cassation of July 23, 2020, case No. 88-13238/2020. Consultant-Plus Database.

${ }^{6}$ Decision of the District Court of Moscow of December 23, 2020, case No. 2-4857/2020. Consultant-Plus Database.

${ }^{7}$ Appeal Ruling of the Moscow City Court of September 10, 2020, case No. 33-34267. Consultant-Plus Database.

${ }^{8}$ Kurmanaeva, A. (04 March 2021) On Delivery: How the Head of Delivery Club Earned 10 Billion by Working as a Courier. RBC Pro. Available from: https://pro.rbc.ru/news/603f5f419a7947ad36ba8571 [Accessed: 30 April 2021].
} 
establish labor relations with both the aggregator and the service partner, although the functions of the employer are distributed between them ${ }^{9}$.

An analysis of court decisions shows the presence of some classic features of an employment relationship in legal relationships with platform employees, which were not taken into account by the courts. In particular, both couriers and drivers indicate that partners set their working hours ${ }^{10}$.

The courts, refusing to recognize the relationship as labor, indicate that the platform employee (driver) did not provide sufficient and convincing evidence proving the emergence of an employment relationship. The difficulty lies in the fact that in this category of disputes there is no provision for shifting the burden of proof. In addition, platform employees cannot provide formalized documents drawn up in accordance with the requirements of the Labor Code of the Russian Federation, since aggregators and service partners use other information channels for organizing labor (for example, through correspondence in a group formed in the TELEGRAM messenger ${ }^{11}$.

\section{Conclusion}

The emergence of new forms of employment can contribute to both an actual expansion and a narrowing of the scope of application of labor law, which, unfortunately, occurs more often. In cases where legal relations with platform employees are recognized by the labor courts, I think it would be more correct to speak not about expanding the scope of application of labor law, but about preventing its unreasonable narrowing. On the other hand, the expansion of the scope of application of labor law occurs in the case of granting labor rights to those categories of employed persons who were not previously covered by labor law, for example, self-employed or economically dependent self-employed. Expanding the scope of labor law, extending labor and legal guarantees to new categories of the employed population is a long and complex process both at the national and transnational levels. At the European and international level, the first step towards expanding the scope of labor standards is to extend them to persons in precarious employment legal relationships and ensure the effective exercise of labor rights, regardless of the form of employment.

In practice, platform companies unilaterally not only determine the procedure for the provision of services by platform employees, but also predetermine the type of legal relationship with platform employees, allowing access to the service only for self-employed. Determining the scope of labor law (legislation) and signs of an employment relationship should be within the competence of the legislator, and not private entities, such as platform operators and service partners.

When the courts use a formalized approach in disputes about the emergence of labor legal relations with platform employees, the essence of the structure of platform employment remains unrevealed and platform companies can continue to bypass labor legislation. The risk of this approach may be a further increase in the number of bogus self-employed. At the same time, in addition to bogus self-employed couriers and drivers, there will be bogus self-employed representatives of other professions (for example, sellers and hotel workers) who will (have to) offer their services through platforms. Thus, low-wage platform workers who need social protection will be deprived of it.

In order to counter this trend, a new interpretation is necessary by the courts of already existing features of an employment relationship. So, the performance of work under the management and control of the employer includes the implementation of algorithmic control and the performance of work, the provision of services based on the mobile application provided to the platform employed. The long-term nature of the employment relationship follows from the fact that the platform employee is not limited to the execution of individual one-time orders, but carries out such activities on a regular basis.

From the analysis of foreign judicial practice on disputes on the emergence of labor relations with platform employees, it follows that in some countries (for example, in Germany), only the courts of higher instance (after consideration of the dispute by the courts of first and second instance) qualified the legal

\footnotetext{
${ }^{9}$ Appeal Ruling of the Kaluga Regional Court of February 1, 2021, case No. 33-318/2021; Appeal Ruling of the Moscow City Court of September 10, 2020, case No. 33-34267. Consultant-Plus Database.

${ }^{10}$ Decision of the Leninsky District Court of Kirov of December 6, 2017, case No. 2-4168/2017; Appeal Ruling of the Moscow City Courtn of April 12, 2018, case No. 33-15213/2018. Consultant-Plus Database.

${ }^{11}$ Decision of the District Court of Moscow of December 23, 2020, case No. 2-4857/2020. Consultant-Plus Database.
} 
relations arising with platform employees as labor relations. The Supreme Court of the Russian Federation in the Resolution of the Plenum of May 29, 2018 No. 15, as well as in the Determinations ${ }^{12}$ emphasizes the principle of the priority of facts; the need to take into account the signs of an employment relationship set out in the Labor Code, as well as in the ILO Recommendation on the employment relationship; the need for the correct distribution of the burden of proof between the parties of legally significant circumstances. In disputes regarding cases of compensation for damage to causal life and health, the Supreme Court of the Russian Federation ${ }^{13}$ qualified the activities of platform companies as Yandex.Taxi as an activity to provide transport, and not as information services (Chesalina, 2020b). I believe that this has laid a good foundation for the future recognition by the Supreme Court of the Russian Federation of relations with platform employed (drivers and couriers) as labor ones.

In conclusion, it should be noted that in order to prevent the de facto narrowing of the scope of application of labor law, it is also necessary to ensure effective access to social security regardless of the form of employment (for both workers and the self-employed) and remove the negative incentives of privileged tax regulations that induce employers to give preference to self-employed person, not an employee.

\section{References}

Cherry, M. \& Aloisi, A. (2017) 'Dependent Contractors' in the Gig Economy: A Comparative Approach. American University Law Review. 66 (3), 635-689.

Cherry, M. (2021) Proposition 22: A Vote on Gig Workers Status in California. Comparative Labor Law \& Policy Journal. Dispatch 31. Available from: https://cllpj.law.illinois.edu/content/dispatches/2021/ February-Dispatch-2021.pdf. [Accessed 15 April 2021].

Chesalina, O. V. (2020a) Informacionnyj i algoritmicheskij kontrol‘ pri tipichnoj i netipichnoj zanjatosti [Informational and Algorithmic Control in Case of Standard and Non-standard Employment. In: Lyutov, N. \& Sulejmanova, F. (eds.), Tipichnaja i netipichnaja zanjatost': perspektivy issledovanij i regulirovanija. Materialy Mezhdunarodnoj nauchno-prakticheskoj konferencii [Standard and Non-Standard Employment: Research and Regulation Perspectives. Materials of the International Scientific-Practical Conference]. Moscow, RG-Press, 225-229. (in Russian).

Chesalina, O. V. (2020b) Labour Law Guarantees for Platform Workers. Herald of the Euro-Asian Law Congress. (1), 108-117. https://doi.org/10.34076/2619-0672-2020-4-1-108-117. (in Russian).

Choonara, J. (2019) Insecurity, Precarious Work and Labour Markets. Cham, Palgrave Macmillan.

De Stefano, V. (2021) Not as Simple as it Seems: The ILO and the Personal Scope of International Labour Standards. International Labour Review. Available from: https://doi.org/10.1111/ilr.12201 [Accessed: 15 April 2021].

De Stefano, V., Durri, I., Stylogiannis, C. \& Wouters, M. (2021) Platform Work and the Employment relationship. ILO Working Paper 27. Geneva, ILO. Available from: https://www.ilo.org/wcmsp5/groups/ public/---ed_protect/---protrav/---travail/documents/publication/wcms_777866.pdf. [Accessed: 15 April $2021]$.

Diveeva, N. I., Grebenshikov, A. V. \& Kuzmenko, A. V. (2020) Trudovye otnoshenija s internetagregatorom: zavtrashnjaja real'nost' [Labor Relations with Internet Aggregator: Tomorrow's Reality?]. Yearbook of Labour Law. (10), 53-66. (in Russian).

Engler, M. (2019) Fahrradkuriere als Arbeitnehmer. Europäische Zeitschrift für Arbeitsrecht. (4), 504511. (In German).

Gramano, E. \& Stolzenberg, H. (2018) Die Jobs Act-Reform in Italien: Smart 'Regelung' des Weisungsrechts und neuer Rechtsrahmen für Selbständige. Sozialrecht. (5), 195-206. (In German).

Gruber-Risak, M. (2021) There is a Crack, a Crack in Everything. International Union Rights. 28 (1), $14-15$

Gyulavári, T. (2014) Trap of the Past: Why Economically Dependent Work is not Regulated in the Member States of Eastern Europe. European Labour Law Journal. 5 (3-4), 267-278.

${ }^{12}$ Ruling of the Supreme Court of the Russian Federation dated October 21, 2019 No. 78.KG19-30. Consultant-Plus Database.

${ }^{13}$ Resolution of the Plenum of the Supreme Court of the Russian Federation dated June 26, 2018 No. 26 'On Some Issues of the Application of Legislation on the Contract for the Carriage of Goods, Passengers and Luggage by Road and on the Contract for Freight Forwarding'. Consultant-Plus Database. 


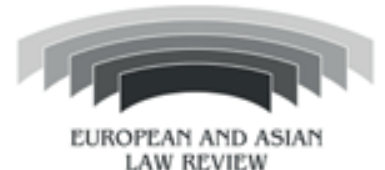

Gyulavári, T. (2020) Casual Work Laws in Eastern Europe. In: Bramshuber, E., Friedrich, M. \& Karl, B. (eds.) Festschrift Franz Marhold. Wien, Manz Verlag, pp. 449-560.

Harris, D. \& Krueger, A. (2015) A Proposal for Modernizing Labor Laws for Twenty-First Century Work: the Independent Worker. Hamilton Project. Discussion Paper. Available from: https://www.hamiltonproject. org/assets/files/modernizing_labor_laws_for_twenty_first_century_work_krueger_harris.pdf. [Accessed: 15 April 2021].

ILAW (2021) Taken for a Ride: Litigating the Digital Platform Model. Issue Brief, March. Available from: https://www.ilawnetwork.com/wp-content/uploads/2021/03/Issue-Brief-TAKEN-FOR-A-RIDE-English.pdf [Accessed: 15 April 2021].

Ivanova, M., Bronowicka, J., Kocher, E. \& Degner, A. (2018) The App as a Boss? Control and Autonomy in Application-Based Management. Arbeit/Grenze/Fluss - Work in Progress interdisziplindrer Arbeitsforschung. No. 2. Frankfurt (Oder), Viadrina. https://doi.org/10.11584/Arbeit-Grenze-Fluss.2.

Joyce, S., Stuart, M., Forde, C. \& Valizade, D. (2019) Work and Social Protection in the Platform Economy in Europe. Advances in Industrial and Labor Relations. (25), 153-184. Available from: http://eprints. whiterose.ac.uk/148824/ [Accessed: 15 April 2021]. https://doi.org/10.1108/S0742-618620190000025009.

Kessler, F. (2021) Social Security in the Platform Economy: The French Example - New Actors, New Regulations, Old Problems? In: Becker, U. \& Chesalina, O. V. (eds.) Social Law 4.0: New Approaches for Ensuring and Financing Social Security in the Digital Age. Baden-Baden, Nomos, pp. 257-280.

Korshunova, T. Yu. (2020) Problems of Decent Labour Under Atypical Employment. Journal of Russian law. (7), 78-98. https://doi.org/10.12737/jrl.2020.082. (in Russian).

Ljutov, N. L. \& Voitkovska, I. V. (2020) Taxi Drivers Performing Work through Online Platforms: What Are the Legal Consequences of Labor 'Uberization'? Actual Problems of Russian Law. 15 (6), 149159. https://doi.org/10.17803/1994-1471.2020.115.6.149-159. (in Russian).

Ljutov, N. L. \& Voitkovska, I. V. (2021) Remote Work and Platform Work: The Prospects for Legal Regulation in Russia. Russian Law Journal. 9 (1), 81-113. https://doi.org/10.17589/2309-8678-2021-9-181-113. (in Russian).

Prassl, J. \& Risak, M. (2017) Working in the Gig-economy - Flexibility without Security? In: Singer, R. \& Bazzani, T. European Employment Policies: Current Challenges. Berlin, Berliner Juristische Universitдtsschriften: Zivilrecht, pp. 87-91.

Prassl, J. (2018) Humans as a Service. Oxford, Oxford University Press.

Shuraleva, S. V. (2019) Rabotniki v 'oblakah': vlijanie internet-platform na razvitie trudovyh otnoshenij [Cloud Employees: The Influence of Internet Platforms on Development of Labour Relationships]. Labor Law in Russia and Abroad. (1), 15-18. (in Russian).

Zaitseva, L. V. \& Mitryasova, A. S. (2018) Trud voditelej taksi na osnove internet-platform: otdel'nye voprosy pravovogo regulirovanija [Labor of taxi drivers on the basis of internet platforms: Some issues of legal regulation]. Vestnik Tomskogo gosudarstvennogo universiteta. (435), 239-245. (in Russian).

\section{Information about the author}

Olga V. Chesalina - Candidate of Juridical Sciences, Associate Professor, LL.M., Senior Researcher of Max-Planck-Institute for Social Law and Social Policy, Munich, Germany (33 Amalienstr., Munich, Germany, e-mail: ol15ga@yandex.ru).

(c) O. V. Chesalina, 2021

Date of Paper Receipt: May 2, 2021

Date of Paper Approval: June 4, 2021

Date of Paper Acceptance for Publishing: July 26, 2021 